\title{
PARTISIPASI PETANI DALAM PROGRAM PENGEMBANGAN USAHA AGRIBISNIS PEDESAAN (PUAP) DI KECAMATAN ADILUWIH KABUPATEN PRINGSEWU
}

\author{
(Participation of Farmers in Rural Agribusiness Development Program \\ in Adiluwih District, Pringsewu Regency)
}

Rika ES Sitompul, Kordiyana K Rangga, Begem Viantimala

Jurusan Agribisnis, Fakultas Pertanian, Universitas Lampung, Jl. Prof. Dr. Soemantri Brodjonegoro No.1 Bandar Lampung 35145, Telp. 082175290052, e-mail: rika.esterr@ gmail.com

\begin{abstract}
The objectives of this research are to know the participation of farmers in PUAP program, factors related to farmers' participation in PUAP program, and farmers' income. This research was conducted in Bandung Baru Village of Adiluwih District, Pringsewu Regency. The sampling used was proportional random sampling with total of 81 farmers. The research was conducted in October - December 2016. The research method is a survey. The relationship between the variables was tested using Rank Spearman correlation test. The results showed that farmers' participation in the PUAP program was quite active, factors related to farmers' participation were age, education level, length of farming experience, and cultivated land area. Average household income of farmers in Bandung Baru Village Adiluwih District Pringsewu Regency each year is Rp67.633.851.
\end{abstract}

Key words: income, participation, PUAP program

\section{PENDAHULUAN}

Pembangunan ekonomi di Indonesia saat ini masih dihadapkan dengan masalah kemiskinan.Pada umumnya di negara berkembang seperti Indonesia, permasalahan pendapatan yang rendah dengan masalah kemiskinan merupakan permasalahan utama dalam pembangunan ekonomi. Salah satu sektor yang berperan dalam mengentaskan kemiskinan adalah sektor pertanian. Sektor pertanian menjadi salah satu komponen pembangunan nasional dalam menuju swasembada pangan. Salah satu cara yang dapat menunjang pembangunan ekonomi nasional yaitu dengan meningkatkan mutu dan kualitas pada sektor pertanian.

Permasalahan mendasar pada petani yang membuat petani Indonesia miskin dan tidak sejahtera karena lemahnya sistem organisasi kelompok tani seperti meningkatkan fasilitas bantuan dan akses permodalan, meningkatkan fasilitas dan pembinaan kepada organisasi kelompok, dan meningkatkan efisiensi dan efektivitas usahatani, dan dalam penggunaan teknologi. Sistem permodalan yang dianggap petani rumit membuat petani yang memiliki pengetahuan yang sedikit menjadi merasa tidak antusias. Hal ini yang menjadi alasan pemerintah membuat program Pengembangan Usaha Agribisnis Pedesaan (PUAP) sebagai program dana bantuan dalam usaha masyarakat tani. Program PUAP merupakan bantuan modal usaha Gabungan Kelompok Tani (Gapoktan) dalam menumbuhkambangkan usaha agribisnis sesuai dengan potensi pertanian desa sasaran. Pada tahun 2015 salah satu kabupaten yang menerima program PUAP adalah Kabuapten Pringsewu dengan jumlah gapoktan penerima PUAP, yaitu 16 gapoktan (BPTP Provinsi Lampung 2015).

Permasalahan yang terjadi pada pengelolaan dana aset PUAP di Kecamatan Adiluwih, yaitu permasalahan secara internal dalam kepengurusan dan pengembalian modal yang tidak lancar atau macet. Menurut BPTP tidak lancarnya pengembalian modal disebabkan oleh rendahnya partisipasi petani dalam mengikuti penyuluhan, yang mengakibatkan kurangnya pehamanan petani tentang pemberian modal sehingga petani tidak melakukan kewajibannya untuk mengembalikan modal. Tingkat pengembalian modal yang rendah akan berpengaruh pada pemberian modal bagi calon petani selanjutnya. Pelaksanaan program PUAP membutuhkan partisipasi petani dalam berbagai kegiatan yang diadakan karena pada dasarnya petanilah yang melaksanakan kegiatankegiatan yang ada dalam program.

Pelaksanaan program PUAP harus diiringi dengan partisipasi petani karena pada dasarnya petanilah yang melaksanakan kegiatan-kegiatan yang ada 
pada program. Keikutserataan petani yang tinggi dapat mewujudkan tercapainya tujuan program PUAP. Penelitian ini bertujuan untuk mengetahui tingkat partisipasi petani dalam program PUAP di Kecamatan Adiluwih, faktor-faktor yang mempengaruhi partisipasi petani, dan pendapatan petani peserta program PUAP di Kecamatan Adiluwih.

\section{METODE PENELITIAN}

Metode penelitian yang digunakan adalah metode survei yaitu penelitian yang mengambil sampel dari suatu populasi menggunakan kuesioner sebagai pengumpul data. Penelitian ini dilakukan pada bulan Okober - Desember 2016 di Desa Bandung Baru Kecamatan Adiluwih Kabupaten Pringsewu. Jumlah responden petani PUAP adalah 81 responden dengan metode pengambilan sampel adalah proportional random sampling.

Data yang digunakan dalam penelitian adalah data primer dan data sekunder. Data primer diperoleh melalui, wawancara secara langsung dengan petani di Kecamatan Adiluwih dengan mengajukan pertanyaan-pertanyaan, seperti pendapatan, dan kehadiran petani dalam penyuluhan. Data sekunder diperoleh dari berbagai instansi seperti Dinas Pertanian, Balai Penelitian Tanaman Pangan (BPTP) Provinsi Lampung, Kantor Kecamatan, Balai Penyuluhan Pertanian, Perikanan dan Kahutanan (BP3K).

Partisipasi petani dalam pelaksanaan program PUAP di Desa Bandung Baru diperoleh dengan menggunakan analisis data deskriptif kualitatif, melalui kuesioner dengan empat indikator partipasi (Y) yaitu partisipasi dalam perencanaan dan pengambilan keputusan, pasrtisiasi dalam kegiatan atau pelaksanaan, partisipasi dalam monitoring dan evaluasi kegiatan, dan partisipasi dalam pemanfaatan dan menikmati hasil. Faktorfaktor yang diduga berhubungan dengan tingkat partisipasi petani (X) yaitu usia, tingkat pendidikan, lama berusahatani, dan luas lahan garapan, diukur menggunakan skor 1 sampai 3 dan diklasifikasikan menjadi kurang baik, cukup baik, dan baik, dengan ketentuan klasifikasi menggunakan rumus Sturges (Dajan 1996).

Untuk mengetahui hubungan antar variabel digunakan uji korelasi Rank Spearman dan untuk menguji tingkat signifikansi hubungan yang diambil lebih dari $30 \quad(\mathrm{~N}>30)$ dengan tingkat kepercayaan 95 persen dengan rumus (Siegel 1997)

\section{Analisis Pendapatan}

Analisis pendapatan usahatani merupakan selisih antara total penerimaan yang diterima dari hasil usahatani dengan total biaya produksi yang dikeluarkan. Secara matematis untuk menghitung pendapatan usahatani dapat digunakan rumus Rahim dan Hastuti (2008). Untuk mengetahui usahatani peserta PUAP menguntungkan atau tidak secara ekonomi dapat dianalisis dengan menggunakan nisbah atau perbandingan antara penerimaan dengan biaya (Revenue Cost Ratio). Pendapatan rumah tangga merupakan pendapatan yang berasal dari usahatani (on farm), usahatani lain (off farm), dan dari luar usaha pertanian (nonfarm).

\section{HASIL DAN PEMBAHASAN}

\section{Karakteristik Responden}

Responden dalam penelitian ini merupakan petani peserta dalam kegiatan program PUAP. Usia ratarata responden pada penelitian adalah 52 tahun yang termasuk dalam kategori usia produktif. Rata-rata lama petani dalam berusahatani adalah 19 tahun yang termasuk dalam kategori cukup lama berusahatani. Status kepemilikan lahan petani yaitu milik sendiri dengan rata-rata luas lahan yang dimiliki adalah 1 ha. Rata-rata jumlah tanggungan keluarga petani responden sebanyak 3 jiwa. Pekerjaan petani peserta PUAP mencakup on farm, off farm, dan non farm.

\section{Deskripsi Variabel}

\section{Tingkat Partisipasi Petani dalam Program PUAP di Desa Bandung Baru}

Variabel $\mathrm{Y}$ tingkat partisipasi petani peserta PUAP di Desa Bandung Baru Kecamatan Adiluwih pada penelitian ini dilihat dari empat indikator, yaitu tingkat partisipasi petani dalam perencanaan dan pengambilan keputusan, partisipasi petani dalam pelaksanaan kegiatan, partisipasi petani dalam monitoring dan evaluasi hasil, dan partisipasi petani dalam pemanfaatan dan menikmati hasil (Pamudji 1997).

Berdasarkan keempat indikator partisipasi tersebut secara keseluruhan tingkat partisipasi petani di Desa Bandung Baru Kecamatan Adiluwih dapat dilihat pada Tabel 1. 
Tabel 1. Indikator skor partisipasi petani pada program PUAP

\begin{tabular}{llcc}
\hline $\begin{array}{c}\text { Tingkat Partisipasi } \\
\text { Petani dalam } \\
\text { Program PUAP }\end{array}$ & Klasifikasi & $\begin{array}{c}\text { Jumlah } \\
\text { (orang) }\end{array}$ & $(\%)$ \\
\hline $19,01-26,89$ & Rendah & 29 & 35,80 \\
$26,90-24,78$ & Cukup & 33 & 40,75 \\
$34,79-42,76$ & Tinggi & 19 & 23,45 \\
\hline Jumlah & 81 & 100 \\
Skor Rata-rata: 29,53 (cukup) & & \\
\hline
\end{tabular}

Tabel 1 menunjukkan terdapat 33 jiwa $(40,75 \%)$ menyatakan tingkat partisipasi berada pada klasifikasi cukup, 29 jiwa $(35,80 \%)$ berada pada klasifikasi rendah, dan terdapat 19 jiwa $(23,45 \%)$ berada pada klasifikasi tinggi. Ratarata skor tingkat partisipasi petani dalam mengikuti program PUAP yaitu 29,58 yang berada dalam klasifikasi cukup. Halini menunjukkan keaktifan petani dalam partisipasi petani pada perencanaan dan pengambilan keputusan, partisipasi petani dalam pelaksanaan, partisipasi petani dalam monitoring, dan partisipasi petani dalam pemanfaatan program PUAP di Desa Bandung Baru sudah dilaksanakan dengan cukup baik.Partisipasi diartikan tidak hanya menyumbang tenaga, tetapi partisipasi harus diartikan lebih luas, yaitu harus menyangkut taraf perencanaan, pelaksanaan, dan pemanfaatan. Secara ekonomis, partisipasi masyarakat dalam pembangunan akan meningkatkan aktivitas petani tersebut dalam mengolah sumber daya alam dan sumber daya manusia, yang pada akhirnya akan meningkatkan pendapatan petani. Fungsi utama dari partisipasi yaitu untuk menumbuhkan kesadaran bagi petani untuk turut serta bertanggung jawab dan mempunyai rasa memiliki dalam merencanakan serta menikmati hasil-hasil.

\section{Partisipasi Dalam Perencanaan dan Pengambilan Keputusan}

Partisipasi dalam perencanaan dan pengambilan keputusan merupakan keikutsertaan atau keterlibatan petani dalam dalam memberikan gagasan atau ide yang menyangkut kepentingan bersama dan ikut serta dalam pengambilan keputusan dalam upaya tercapainya sebuah tujuan. Klasifikasi dan sebaran partisipasi petani peserta PUAP di Desa Bandung Baru dalam perencanaan dan pengambilan keputusan dapat dilihat pada Tabel 2.
Tabel 2. Klasifikasi dan sebaran partisipasi petani dalam perencanaan dan pengambilan keputusan

\begin{tabular}{llcc}
\hline Interval & & \multicolumn{2}{c}{ Petani peserta } \\
\cline { 3 - 4 } $\begin{array}{c}\text { Perencanaan dan } \\
\text { pengambilan } \\
\text { keputusan (skor) }\end{array}$ & Klasifikasi & & \multicolumn{2}{c}{ Jumlah } \\
\cline { 3 - 4 } & & Jiwa & $(\%)$ \\
\hline $4,00-7,22$ & Rendah & 28 & 34,56 \\
$7,23-10,45$ & Cukup & 34 & 41,98 \\
$10,46-13,68$ & Tinggi & 19 & 23,46 \\
\hline Jumlah & & 81 & 100 \\
\hline Rata-Rata petani PUAP : 8,55 (cukup) & & \\
\hline
\end{tabular}

Tabel 2 menunjukkan sebanyak 41,98 persen petani peserta PUAP di Desa Bandung Baru menyatakan bahwa tingkat partisipasi petani dalam perencanaan dan pengambilan keputusan berada pada klasifikasi cukup $(7,23-10,45)$. Skor rata-rata tingkat partisipasi petani peserta PUAP dalam perencanaan dan pengambilan keputusan di Desa Bandung Baru 8,55 dan termasuk dalam klasifikasi cukup.

Berdasarkan hasil penelitian cukupnya tingkat partisipasi petani dalam pelaksanaan program PUAP di Desa Bandung Baru dikarenakan keikutsertaan petani yang cukup baik dalam mengikuti setiap pelaksanaan program-program serta partisipasi petani yang cukup baik dalam menyumbangkan tenaga kerja, artinya keaktifan dan keikutsertaan petani dalam menghadiri setiap pertemuan dalam melaksanakan perencanaan pembentukan program, memberikan gagasan atau ide cukup aktif karena petani mempunyai peran dalam setiap kegiatan yang bertujuan untuk mencapai tujuan kelompok tersebut

\section{Partisipasi Dalam Pelaksanaan Kegiatan}

Partisipasi petani dalam pelaksanaan kegiatan, yaitu keterlibatan dalam penyediaan dana, pengadaan sarana dan pengorbanan waktu, tenaga sejak persiapan kegiatan, pelaksanaan kegiatan pasca kegiatan berupa pemeliharaan hasil-hasil kegiatan. Faktor yang mendorong petani untuk berpartisiapsi pada pelaksanaan program PUAP adalah kesadaran dan keinginan petani untuk meningkatkan pendapatan masing-masing petani. Klasifikasi dan sebaran partisipasi petani peserta PUAP dalam pelaksanaan kegiatan di Desa Bandung Baru dapat dilihat pada Tabel 3. 
Tabel 3. Klasifikasi partisipasi petani dalam pelaksanaan kegiatan

\begin{tabular}{llcc}
\hline \multirow{2}{*}{$\begin{array}{c}\text { Interval } \\
\text { pelaksaanaan } \\
\text { kegiatan (skor) }\end{array}$} & Klasifikasi & \multicolumn{2}{c}{ Petani Peserta PUAP } \\
\cline { 3 - 4 } & & $\begin{array}{c}\text { Jumlah } \\
\text { Jiwa }\end{array}$ & $(\%)$ \\
\hline $3,00-5,27$ & Rendah & 22 & 27,16 \\
$5,28-7,55$ & Cukup & 33 & 40,75 \\
$7,56-10,33$ & Tinggi & 26 & 32,09 \\
\hline Jumlah & & 81 & 100 \\
\hline \multicolumn{2}{l}{ Rata-rata petani PUAP : 6,29 (cukup) } \\
\hline
\end{tabular}

Berdasarkan hasil penelitian,menunjukkan sebanyak 40,75 persen pertisipasi petani peserta PUAP dalam pelaksaan kegiatan berada dalam klasifikasi cukup dengan skor $(5,28-7,61)$. Skor rata-rata tingkat partisipasi petani peserta PUAP dalam pelaksanaan kegiatan di Desa Bandung Baru 6,27 dan termasuk dalam klasifikasi cukup.

Cukupnya tingkat partisipasi petani dalam pelaksanaan program PUAP di Desa Bandung Baru dikarenakan keikutsertaan petani yang cukup baik dalam mengikuti setiap pelaksanaan program-program serta partisipasi petani yang cukup baik dalam menyumbangkan tenaga kerja.. Keaktifan yang tinggi ataupun rendah dalam pelaksanaan program dapat mengakibatkan tercapai atau tidaknya tujuan dalam sebuah program sehingga tujuan dari program PUAP dapat dikatakan sudah cukup tercapai, karena petani peserta PUAP dengan mudahnya mendapatkan pinjaman dana.

\section{Partisipasi Dalam Monitoring dan Evaluasi Hasil}

Partisipasi dalam monitoring dan evaluasi hasil merupakan ikut sertanya petani dalam memberikan penilaian sampai seberapa jauh tujuan program dicapai. Partisipasi dalam monitoring dan evaluasi hasil yaitu, partisipasi petani dalam memonitoring dan mengevaluasi terpenuhinya kebutuhan tenaga kerja, mengevaluasi bagaimana jalannya program PUAP dengan kesesuaian rencana, serta melihat kualitas hasil yang diterima petani pada program PUAP. Klasifikasi dan sebaran partisipasi dalam monitoring dan evaluasi hasil dapat dilihat pada Tabel 4.

Tabel 4 menunjukkan bahwa sebanyak 39,50 persen petani peserta PUAP yang menyatakan tingkat partisipasi petani dalam monitoring dan evaluasi hasil masuk dalam klasifikasi cukup dengan skor $(8,87-11,81)$. Skor rata-rata peserta
PUAP pada partisipasi dalam monitoring dan evaluasi hasil dalam hal ini adalah sebesar 9,81 yang termasuk dalam kalsifikasi cukup.

Berdasarkan hasil penelitian, didapatkan bahwa partisipasi petani peserta PUAP dalam monitoring dan evaluasi hasil termasuk ke dalam klasifiasi cukup. Hal ini menunjukkan bahwa tidak semua petani peserta PUAP ikutserta dalam memonitoring dan mengevaluasi jalannya program PUAP, seperti melihat apakah program berjalan sesuai dengan perencanaan yang telah dimusyawarahkan bersama, apakah kebutuhan tenaga kerja telah terpenuhi, apakah petani peserta PUAP ikut melihat dan menilai jalannya program PUAP.

\section{Partisipasi Petani Dalam Pemanfaatan dan Menikmati Hasil}

Partisipasi dalam pemanfaatan dan menikmati hasil, yaitu manfaat yang diperoleh petani setelah mengikuti program PUAP, keuntungan ekonomi yang diperoleh peserta PUAP setelah mengikuti program PUAP. Partisipasi dalam pemanfaatan dan menikmati hasil dapat dilihat dari segi kualitas yaitu output, sedangkan dari segi kuantitas dapat dilihat dari persentase keberhasilan program. Keikutsertaan petani dalam pemanfaatan dan menikmat sangat di perlukan guna mencapai tujuan suatu program. Klasifikasi dan sebaran partisipasi dalam pemanfaatan dan menikmati hasil dapat dilihat pada Tabel 5.

Tabel 4. Klasifikasi dan sebaran partisipasi dalam monitoring dan evaluasi hasil

\begin{tabular}{cccc}
\hline \multirow{2}{*}{$\begin{array}{c}\text { Interval monitoring } \\
\text { dan evaluasi hasil } \\
\text { (skor) }\end{array}$} & Klasifikasi & \multicolumn{2}{l}{ Petani peserta PUAP } \\
\cline { 3 - 4 } & & $\begin{array}{l}\text { Jumlah } \\
\text { Jiwa }\end{array}$ & $(\%)$ \\
\hline $5,29-8,86$ & Rendah & 30 & 37,03 \\
$8,87-11,81$ & Cukup & 32 & 39,50 \\
$11,82-14,76$ & Tinggi & 19 & 23,45 \\
\hline Jumlah & \multicolumn{3}{c}{81} \\
\hline \multicolumn{2}{c}{ Rata-rata petani peserta PUAP : 9,81 (cukup) } \\
\hline
\end{tabular}

Tabel 5. Partisipasi dalam pemanfaatan dan menikmati hasil di Desa Bandung Baru

\begin{tabular}{cccc}
\hline \multirow{2}{*}{$\begin{array}{c}\text { Interval pemanfaatan } \\
\text { dan menikmati hasil } \\
\text { (skor) }\end{array}$} & Klasifikasi & \multicolumn{3}{c}{ Petani peserta } \\
\cline { 3 - 4 } & & $\begin{array}{c}\text { JumAP } \\
\text { Jiwa }\end{array}$ & $(\%)$ \\
\hline $3,00-4,62$ & Rendah & 34 & 41,97 \\
$4,63-6,25$ & Cukup & 36 & 44,44 \\
$6,26-7,88$ & Tinggi & 11 & 13,59 \\
\hline Jumlah & & 81 & 100 \\
\hline Rata-rata petani peserta PUAP : 4,88 (cukup) \\
\hline
\end{tabular}


Tabel 5 menunjukkan skor rata-rata petani peserta PUAP pada partisipasi petani dalam pemanfaatan dan menikmati hasil pada program PUAP adalah sebesar 4,88 dan termasuk dalam klasifikasi cukup. Berdasarkan hasil penelitian, didapatkan bahwa ada sebagian petani peserta PUAP telah mendapatkan manfaat yang banyak, yaitu petani mengganggap dengan mengikutinya program PUAP dapat menguntungkan secara ekonomi. Dana yang didapat dari program PUAP ini digunakan untuk pupuk sehingga petani tidak perlu memikirkan biaya pupuk karena dapat dikembalikan setelah petani menerima keuntungan dari usahataninya.

\section{Deskripsi Variabel X}

Variabel $X$ adalah faktor-faktor yang berhubungan dengan partisipasi program PUAP di Desa Bandung Baru terdiri dari usia $\left(\mathrm{X}_{1}\right)$, tingkat pendidikan petani $\left(\mathrm{X}_{2}\right)$, lama berusahatani $\left(\mathrm{X}_{3}\right)$, dan luas lahan garapan $\left(\mathrm{X}_{4}\right)$.

\section{$\operatorname{Usia}\left(\mathbf{X}_{1}\right)$}

Usia dalam penelitian ini adalah usia responden dari awal kelahiran sampai pada saat penelitian ini dilakukan. Penelitian ini ingin melihat golongan usia petani yang mengikuti program PUAP dan dikaitkan dengan partisipasi mereka.

Usia produktif secara ekonomi dapat dibagi menjadi tiga kelompok usia yaitu, kelompok 0 14 tahun merupakan kelompok usia belum produktif, kelompok 15 - 64 tahun merupakan kelompokusia produktif, dan kelompok usia di atas 65 tahun merupakan kelompok usia yang tidak produktif menurut Mantra (2004). Sebaran responden berdasarkan usia petani dapat diilihat pada tabel 6 .

Berdasarkan hasil penelitian, diketahui bahwa sebanyak 42 jiwa $(51,85 \%)$ berada dalam klasifikasi setengah baya, 20 jiwa $(24,70 \%)$ berada dalam klasifikasi tua, dan sebanyak 19 jiwa $(23,45 \%)$ petani berada dalam klasifikasi muda. Rata-rata usia petani responden yaitu 46 tahun dengan klasifikasi setengah baya. Hal ini menunjukkan bahwa sebgaian besar petani responden peserta PUAP di Desa Bandung Baru masih dalam usia produktif.

\section{Tingkat Pendidikan Formal $\left(\mathbf{X}_{2}\right)$}

Tingkat pendidikan merupakan pendidikan formal terakhir yang ditempuh atau diselesaikan oleh petani yang mengikuti Program PUAP. Tingkat pendidikan seorang petani dapat mempengaruhi pola pikir dan kemampuannya dalam menerima dan mengadopsi teknologi, inovasi serta pembaharuan lain yang dapat meningkatkan kemampuan dirinya, pengetahuan yang diperoleh secara formal tersebut berakibat pada setiap individu yang memiliki pola pikir, perilaku yang sesuai dengan pendidikan yang diperolehnya.

Berdasarkan hasil penelitian, diketahui sebanyak 36 jiwa $(44,44 \%)$ berpendidikan SMA, 26 jiwa $(32,10 \%)$ berpendidikan SMP, 19 jiwa $(23,46 \%)$ berpendidikan sarjana. Mayoritas tingkat pendidkan formal petani peserta PUAP adalah SMA $(44,44 \%)$ yang berada dalam klasifikasi sedang. Sebaran responden berdasarkan tingkat pendidikan formal petani dapat dilihat pada Tabel 7.

\section{Lama Berusahatani $\left(\mathbf{X}_{3}\right)$}

Lama berusahatani adalah lamanya seseorang telah menjadi petani/bekerja di bidang pertanian. Pengalaman seseorang dalam berusahatani berpengaruh dalam menerima inovasi dari luar. Petani yang sudah lama bertani akan lebih mudah menerapkan inovasi dari pada petani pemula. Mengingat bahwa PUAP merupakan suatu bentuk inovasi dalam bidang pertanian dengan pengalaman yang lebih tinggi cenderung merespon PUAP lebih baik dibanding dengan petani pemula/kurang berpengalaman (Soekartawi 1999).

Tabel 6. Sebaran responden berdasarkan usia petani

\begin{tabular}{cccc}
\hline $\begin{array}{c}\text { Usia } \\
\text { (Tahun) }\end{array}$ & Klasifikasi & $\begin{array}{c}\text { Jumlah } \\
\text { (orang) }\end{array}$ & $\begin{array}{c}\text { Persentase } \\
(\%)\end{array}$ \\
\hline $25-38$ & Muda & 19 & 23,45 \\
$49-52$ & Setengah baya & 42 & 51,85 \\
$53-66$ & Tua & 20 & 24,70 \\
\hline Jumlah & \multicolumn{3}{c}{81} \\
\hline \multicolumn{2}{l}{ Rata-rata $=46$ tahun (setengah baya) } \\
\hline
\end{tabular}

Tabel 7. Sebaran responden berdasarkan tingkat pendidikan formal petani

\begin{tabular}{lccc}
\hline \multicolumn{1}{c}{ Pendidikan } & Klasifikasi & $\begin{array}{c}\text { Jumlah } \\
\text { (orang) }\end{array}$ & $\begin{array}{c}\text { Persentase } \\
(\%)\end{array}$ \\
\hline SMP & Rendah & 26 & 32,10 \\
SMA & Sedang & 36 & 44,44 \\
Sarjana & Tinggi & 19 & 23,46 \\
\hline Jumlah & & 81 & 100,00 \\
\hline Rata-rata: SMA (sedang) & & \\
\hline
\end{tabular}


Berdasarkan hasil penelitian, diketahui sebanyak 34 jiwa $(41,98 \%)$ berada pada klasifikasi cukup lama dalam berusahatani, 24 jiwa $(29,62 \%)$ berada dalam klasifikasi lama, dan 23 jiwa $(28,40 \%)$ petani peserta PUAP berada pada klasifikasi baru dalam berusahatani. Sebaran responden berdasarkan tingkat lama petani dalam berusahatani dapat dilihat pada Tabel 8 .

\section{Luas Lahan $\left(\mathbf{X}_{4}\right)$}

Luas lahan adalah luas bidang tanah yang dikuasai oleh petani untuk digunakan kegiatan usaha tani baik hak milik maupun hak menggarap yang dinyatakan dalam satuan hektar (ha). Seluruh petani penerima bantuan program PUAP di Desa Bandung Baru mengalokasikan dana PUAP tersebut pada peningkatan produksi usaha tani jagung, padi, dan kakao, sehingga skala produksi petani penerima program PUAP dipengaruhi juga oleh luas lahan petani.

Berdasarkan hasil penelitian, diketahui sebanyak 44 jiwa $(54,32 \%)$ menunjukkan luas lahan dalam klasifikasi sedang, 20 jiwa (24,7\%) menunjukkan luas lahan luas dalam klasifikasi sempit, dan sebanyak 17 jiwa $(20,98 \%)$ menunjukkan luas lahan dalam klasifikasi luas. Rata-rata luas lahan pertanian petani adalah 1 ha.Sebaran responden berdasarkan luas lahan petani dapat dilihat pada Tabel 9.

Tabel 8. Sebaran petani berdasarkan tingkat lama berusahatani petani

\begin{tabular}{cccc}
\hline $\begin{array}{c}\text { Lama } \\
\text { berusahatani }\end{array}$ & Klasifikasi & $\begin{array}{c}\text { Jumlah } \\
\text { (orang) }\end{array}$ & $\begin{array}{c}\text { Persentase } \\
(\%)\end{array}$ \\
\hline $8-17$ & Baru & 23 & 28,40 \\
$18-27$ & Cukup Lama & 34 & 41,98 \\
$28-36$ & Lama & 24 & 29,62 \\
\hline Jumlah & & 81 & 100,00 \\
\hline Rata-rata: 20 tahun (sedang) & & \\
\hline
\end{tabular}

Tabel 9. Sebaran responden berdasarkan luaslahan petani

\begin{tabular}{lccc}
\hline Luas Lahan & Klasifikasi & $\begin{array}{c}\text { Jumlah } \\
\text { (orang) }\end{array}$ & $\begin{array}{c}\text { Persentase } \\
(\%)\end{array}$ \\
\hline $0,25-0,83$ & Sempit & 20 & 24,70 \\
$0,84-1,42$ & Sedang & 44 & 54,32 \\
$1,43-2,00$ & Luas & 17 & 20,98 \\
\hline Jumlah & 81 & 100,00 \\
\hline Rata-rata: 1 ha (sedang) & & \\
\hline
\end{tabular}

\section{Pengujian Hipotesis}

Hasil ujikorelasi Rank Spearman faktor-faktor yang berhubungan dengan tingkat partisipasi petani pada program PUAP dapat dilihat pada Tabel 10.

Berdasarkan Tabel 10 diperoleh nilai koefisien korelasi rank spearman antara usia $\left(\mathrm{X}_{1}\right)$ dan tingkat partisipasi pada program PUAP (Y) menunjukkan terdapat hubungan antara usia $\left(\mathrm{X}_{1}\right)$ dan tingkat partisipasi petani $(\mathrm{Y})$ dalam program PUAP di Desa Bandung Baru Kecamatan Adiluwih. Hal ini berarti, semakin tinggi usia petani maka semakin tinggi tingkat partisipsi petani pada program PUAP di Desa Bandung Baru. Hal ini tidak sejalan dengan penelitian yang dilakukan Antika, Dewangga, dan Prayitno (2017) yang menyatakan bahwa usia berhubungan nyata dengan partisipasi petani.

Hubungan yang nyata antara usia petani peserta program PUAP dengan tingkat partisipasi petani dikarenakan umur yang produktif sangat memacu petani untuk lebih aktif dalam segala hal, semakin produktif umur seseorang maka semakin tinggi pula semangat yang mereka miliki karena masih mempunyai daya tahan tubuh dan tenaga yang baik.

Hasil pengujian hipotesis antara tingkat pendidikan formal petani $\left(\mathrm{X}_{2}\right)$ dengan tingkat partisipasi petani (Y) menunjukkan terdapat hubungan antara tingkat pendidikan formal petani $\left(\mathrm{X}_{2}\right)$ dan tingkat partisipasi (Y) dalam program PUAP. Hal ini berarti, semakin tinggi tingkat pendidikan petani maka semakin tinggi keikutsertaan atau partisipasi petani dalam program PUAP.

Program PUAP merupakan program bantuan modal yang bertujuan untuk mengembangkan usaha agribisnis di pedesaan sesuai dengan potensinya. Dengan demikian petani dengan pengetahuan lebih tinggi umumnya akan beranggapan berpartisipasi dalam Program PUAP merupakan sebagai upaya positif untuk mengembangkan diri. Hal ini sejalan dengan penelitian yang dilakukan Widyanti, Gitosaputro, dan Yanfika (2015) yang menyatakan bahwa tingkat pendidikan berhubungan nyata dengan partisipasi petani.

Hasil pengujian hipotesis antara pengalaman berusahatani petani $\left(\mathrm{X}_{3}\right)$ dengan tingkat partisipasi petani (Y) menunjukkan terdapat hubungan antara 
pengalaman berusahatani petani $\left(\mathrm{X}_{3}\right)$ dan tingkat partisipasi (Y) dalam program PUAP. Artinya, petani yang memiliki tingkat pengalaman berusahatani tinggi maka semakin tinggi partisipasi petani dalam mengikuti program PUAP. Petani yang sudah lebih lama bertani akan lebih mudah menerapkan inovasi dari pada petani pemula. Mengingat bahwa PUAP merupakan suatu bentuk inovasi dalam bidang pertanian guna meningkatkan usaha agribisnis maka petani dengan pengalaman yang lebih tinggi cenderung merespon PUAP lebih baik.

Hasil pengujian hipotesis antara luas lahan garapan petani $\left(\mathrm{X}_{4}\right)$ dengan tingkat partisipasi petani $(\mathrm{Y})$ menunjukkan terdapat hubungan antara luas lahan garapan petani $\left(\mathrm{X}_{4}\right)$ dan tingkat partisipasi (Y) dalam program PUAP. Artinya, petani yang memiliki luas lahan yang cukup luas lebih berani untuk melakukan inovasi-inovasi baru pada usaha pertaniannya, karena apabila petani gagal dalam melakukan inovasi-inovasi baru, petani yang memiliki luas lahan yang cukup luas masih mempunyai sebagian lahan untuk usaha pertaniannya. Mengingat bahwa PUAP merupakan suatu bentuk inovasi dalam bidang pertanian guna meningkatkan usaha agribisnis maka petani dengan luas lahan yang cukup luas cenderung merespon PUAP lebih baik.

\section{Analisis Usahatani}

Pola tanam di daerah penelitian merupakan pola tanam monokultur. Penanaman komoditas jagung saat musim hujan (rendeng) dan musim kemarau (gadu), dilakukan selama empat bulan. Penanaman padi saat musim hujan (rendeng) dan musim kemarau (gadu), dilakukan selama empat bulan. Sistem penanaman pada tanaman kakao merupakan tahunan.

Benih yang digunakan oleh petani jagung adalah jenis benih hibrida yaitu, P-27 dan DK-85, untuk tanaman padi menggunakan benih Ciherang. Bibit yang digunakan petani pada tananam kakao berasal dari masing-masing petani, dengan cara membuat bibit kakao sendiri. Penggunaan benih atau bibityang unggul dapat berpengaruh terhadap pendapatan petani.

Pupuk yang digunakan oleh petani jagung, padi, dan kakao yaitu pupuk Urea, pupuk ZA, pupuk SP-36, pupuk NPK, dan pupuk kandang. Pestisida yang digunakan petani setiap komoditas di daerah penelitian beragam seperti fastac, regent, round up, antarcol, furadan, dan gramoxone. Tenaga kerja pada usahatani jagung, padi, dan kakao didominasi tenaga kerja pria, baik dalam keluarga maupun luar keluarga. Berdasarkan hasil penelitian penggunaan tenaga kerja terbesar berasal dari tenaga kerja luar keluarga. Peralatan yang digunakan pada petani jagung, padi, dan kakao yaitu, cangkul, gosrok, sprayer/tank, golok, sabit/arit, dan gergaji dahan, dan gergaji pangkas.

Rata-rata penerimaan usahatani jagung di Desa Bandung Baru pada tahun 2016 pada musim rendengyaitu Rp21.306.560,14 dan pada musim gadu yaitu Rp16.165.488,72. Rata-rata jumlah produksi jagung pada musim rendeng sebesar $7.578,01 \mathrm{~kg} / \mathrm{ha}$ dengan harga Rp2.828,57/kg, dan pada musim tanam gadu produksi tanaman jagung sebesar 5.647,43 $\mathrm{kg} / \mathrm{ha}$ dengan harga $\mathrm{Rp} 2.871,43 / \mathrm{kg}$. Rata-rata penerimaan usahatani padi di Desa Bandung Baru pada musim tanam rendeng sebesar Rp31.415.437,32 dan pada musim tanam gadu sebesar Rp22.262.364,93. Rata-rata jumlah produksi tanaman padi pada musim tanam rendeng yaitu $8.082,68 \mathrm{~kg} / \mathrm{ha}$ dengan harga Rp3.886/kg dan pada musim tanam gadu produksi tanaman padi yaitu $5.638,14 \mathrm{~kg} / \mathrm{ha}$ dengan harga Rp3.948,53/kg. Rata-rata total penerimaan usahatani kakao yaitu Rp19.587.896,25 dan rata-rata jumlah produksi tanaman kakao yaitu sebesar 704,25 kg/ha dengan harga Rp24.205/kg.

\section{Analisis Pendapatan Rumah Tangga Petani}

\section{Pendapatan Rumah Tangga Petani (on farm)}

Pendapatan yang diterima petani pada daerah penilitian diterima dari berbagai sumber. Pendapatan usahatani yang diterima oleh petani adalah selisih dari jumlah penerimaan yang petani terima dengan biaya-biaya yang dikeluarkan oleh petani. Jenis komoditas yang marak ditanami oleh petani responden yaitu jagung, padi sawah, dan kakao.

Tabel 10. Hasil uji Rank Spearman faktor-faktor yang berhubungan dengan tingkat pertispasi petani pada program PUAP

\begin{tabular}{lcccc}
\hline \multicolumn{1}{c}{ Variabel $(\mathrm{X})$} & $\begin{array}{c}\text { Variabel } \\
(\mathrm{Y})\end{array}$ & $\mathrm{r}_{\mathrm{s}}$ & $\mathrm{t}$ hitung & $\begin{array}{c}\text { t-tabel } \\
(\alpha 0,05)\end{array}$ \\
\hline - Usia petani & & 0,487 & $4,957 * *$ & 1,664 \\
- Tingkat & & 0,401 & $3,890 * *$ & \\
$\quad$ pendidikan & Partisipasi & & & \\
- Lama & & 0,552 & $5,882 * *$ & \\
$\quad$ berusahatani & & 0,331 & $3,118 * *$ & \\
- Luas lahan & & &
\end{tabular}


Keberhasilan usahatani yang dilakukan oleh petani ditentukan oleh banyak hal. Petani dikatakan berhasil dalam berusahatani dapat dilihat dari segi produksinya yang tinggi dengan produktivitas yang seimbang dan sejalan dengan produksinya, pemilikan lahan yang solid dan tetap dan tidak tergantung dengan pihak lain, dan pendapatan usahatani yang layak. R/C ratio merupakan perbandingan antara tingkat keuntungan yang diperoleh dengan biaya total yang dikeluarkan selama pemeliharaan.

Berdasarkan hasil penelitian R/C pada tanaman jagung, padi, dan kakao berada di atas 1 . Artinya, usahatani petani peserta PUAP menguntungkan dan layak diusahakan bagi petani di Desa Bandung Baru. Hasil tersebut sejalan dengan penelitian yang dilakukan oleh Sari, Haryono, dan Rosanti (2014) yang menyatakan bahwa R/C pada tanaman jagung di Kecamatan Natar lebih dari 1, yang menunjukkan kesamaan klayakan usaha yang dijalankan oleh petani jagung di daerah lain. Rata-rata penerimaan, biaya, pendapatan dan nisbah penerimaan $(\mathrm{R} / \mathrm{C})$ pada berbagai macam komoditas dapat dilihat pada Tabel 11.

\section{Pendapatan di Luar Kegiatan Budidaya Jagung, Padi, dan Kakao (off farm)}

Pendapatan di luar kegiatan budidaya jagung, padi dan kakao atau off farm yaitu kegiatan yang dilakukan di luar dari kegiatan budidaya yang masih dalam kegiatan pertanian. Pendapatanoff farm di Desa Bandung Baru yaitu, peternak dan buruh tani.

Rata-rata pendapatan petani dari aktivitas di luar budidaya jagung, padi dan kakao yang terdiri dari pendapatan sebagai buruh tani sebesar Rp1.371.428,57. Jumlah petani yang bekerja sebagai buruh tani sebanyak 7 petani responden. Petani berharap dapat meningkatkan pendapatannya dalam kegiatan usaha tani, sehingga kebutuhan hidup sehari-hari dapat terpenuhi

\section{Pendapatan Non Pertanian atau Non Farm}

Pendapatan rumah tangga merupakan indikator penting untuk mengetahui kesejahteraan hidup rumah tangga. Sumber pendapatan rumah tangga digolongkan ke dalam dua sektor, yaitu sektor pertanian (on farm) dan non pertanian (non farm). Sumber pendapatan dari sektor pertanian dapat dirincikan lagi menjadi pendapatan usahatani, budidaya perikanan, ternak, buruh petani, dan lain-lain. Sumber pendapatan dari sektor non pertanian dibedakan menjadi pendapat industri rumah tangga, perdagangan, pegawai, jasa, buruh non petanian serta buruh pertanian lainnya (Sajogyo 1997).

Besarnya pendapatan keluarga yang diperoleh keluarga dari hasil kerja anggota keluarga yang bekerja, akan berpengaruh terhadap pemenuhan kebutuhan hidup sehari-hari.Pendapatan non pertanian petani jagung, padi, dan kakao di Desa Bandung Baru terdiri dari tiga sumber pendapatan, yaitu buruh bangunan sebesar Rp1.750.000,00 dengan jumlah 3 petani, pada kegiatan berdagang dengan pendapatan sebesar Rp9.894.736,84 dengan jumlah 19 petani, sedangkan pada pekerjaan karyawan sebesar Rp6.000.000,00 dengan jumlah 1 petani.Besarnya pendapatan keluarga yang diperoleh keluarga dari hasil kerja anggota keluarga yang bekerja, akan berpengaruh terhadap pemenuhan kebutuhan hidup sehari-hariRata-rata pendapatan rumah tangga petani di Desa Bandung Baru Kecamatan Adiluwih tahun 2016 dapat dilihat pada Tabel 12.

Tabel 11. Rata-rata penerimaan, biaya, pendapatan dan nisbah penerimaan (R/C) pada berbagai macam komoditas

\begin{tabular}{lccc}
\hline \multirow{2}{*}{ Musim } & & R/C & \\
\cline { 2 - 4 } Tanam & Jagung & Padi & Kakao \\
\hline Rendeng & 2,48 & 2,97 & - \\
Gadu & 1,98 & 2,17 & - \\
Tahunan & - & - & 3,02 \\
\hline
\end{tabular}

Tabel 12. Rata-rata pendapatan rumah tangga petani di Desa Bandung Baru Kecamatan Adiluwih tahun 2016

\begin{tabular}{|c|c|c|}
\hline $\begin{array}{l}\text { Sumber Pendapatan } \\
\text { Rumah Tangga Petani }\end{array}$ & $\begin{array}{c}\text { Rata-Rata } \\
\text { Pendapatan } \\
\text { (Rp/tahun) }\end{array}$ & $\begin{array}{c}\text { Persentase } \\
\quad(\%)\end{array}$ \\
\hline $\begin{array}{l}\text { - Pendapatan usahatani } \\
\text { dari kegiatan budidaya } \\
\text { (on farm) }\end{array}$ & 57.599 .379 & 80.49 \\
\hline $\begin{array}{l}\text { - Pendapatan usahatani } \\
\text { di luar kegiatan } \\
\text { budidaya (off farm) }\end{array}$ & 1.371 .429 & 1,53 \\
\hline $\begin{array}{l}\text { - Pendapatan dari usaha } \\
\text { non pertanian (non } \\
\text { farm) }\end{array}$ & 8.663 .043 & 17,98 \\
\hline Jumlah & 67.633 .851 & 100,00 \\
\hline
\end{tabular}


Berdasarkan hasil penelitian rata-rata pendapatan rumah tangga petani yang memberikan kontribusi besar terhadap pendapatan rumah tangga berasal dari pendapatan usahatani dalan kegiatan budidaya atau on farm yaitu sebesar 80.49 persen. Pendapatan usahatani yang berasal dari luar kegiatan budidaya tanaman jagung, padi dan kakao memberikan kontribusi terhadap pendapatan rumah tangga yaitu sebesar 1,53 persen. Pendapatan rumah tangga petani dari usaha non pertanian atau non farm memberikan kontirbusi sebesar 17,98 persen.

\section{KESIMPULAN}

Berdasarkan hasil penelitian disimpulkan bahwa, tingkat partisipasi petani pada program PUAP di Desa Bandung Baru termasuk dalam klasifikasi cukup aktif; faktor-faktor yang berhubungan nyata dengan partisipasi petani pada program PUAP di Desa Bandung Baru Kecamatan Adiluwih adalah, usia $\left(\mathrm{X}_{1}\right)$, tingkat pendidikan $\left(\mathrm{X}_{2}\right)$, lama berusahatani $\left(\mathrm{X}_{3}\right)$, dan luas lahan $\left(\mathrm{X}_{4}\right)$ dan ; ratarata pendapatan rumah tangga petani di Desa Bandung Baru Kecamatan Adiluwih Kabupaten Pringsewu sebesar Rp67.633.851per tahun.

\section{DAFTAR PUSTAKA}

Antika AY, Nikmatullah D, dan Prayitno RT. 2017. Tingkat partisipasi anggota P3A dalam program pengembangan jarigan irigasi (PJI) di Kelurahan Fajar Esuk Kecamatan Pringsewu Kabupaten Pringsewu. JIIA: 5 (3): 335-345. http://jurnal.fp.unila.ac.id/index.php /JIA/article/view/1647/1473. [3 agustus 2017].
BPTP Provinsi Lampung.2015. Perkembangan Dana BLM-PUAP 2010-2015 Kabupaten Pringsewu. Lampung. BPTP Provinsi Lampung.

Dajan A. 1996. Pengantar Metode Statistik. PT Pustaka LP3ES. Jakarta.

Sari DK, Haryono D, dan Rosanti, N. 2014. Analisis pendapatan dan tingkat kesejahteraan rumah tangga petani jagung di Kacamatan Natar Kabupaten Lampung Selatan. JIIA 1 (2): 64-70. http://jurnal. fp.unila.ac.id/index.php/JIA/article/view/562/ 524. [1 Januari 2014].

Mantra I. B. 2004. Demografi Umum. Penerbit Pustaka Pelajar. Yogyakarta.

Pamudji OS. 1997. Menuju Pendekatan Pembangunan yang Partisipatif. Buletin Bina Swadaya Mandiri. Jakarta.

Rahim A dan DR Hastuti. 2008. Pengantar Teori dan Kasus Ekonomi Pertanian. Penebar Swadaya. Jakarta.

Sajogyo.1997. Garis Kemiskinan dan Kebutuhan Minimum Pangan. LPSB-IPB. Bogor.

Siegel S. 2011. Statistik Nonparametrik Untuk Ilmu-Ilmu Sosial, Terjemahan. PT Gramedia. Jakarta

Soekartawi. 1999. Analisis Usahatani. Cetakan ke 2. UI-Press. Jakarta.

Widyanti E, Gitosaputro S, dan Yanfika H. 2015. Kebutuhan dan partisipasi masyarakat dalam program kemitraan dan bina lingkungan (PKBL) PTPN VII Unit Usaha Rejosari Kecamatan Natar Kabupaten Lampung Selatan. JIIA: 3 4(2): 195-202. http:// jurnal.fp.unila.ac.id/index.php/JIA/article/vie w/1039/944. [2 April 2015]. 